\title{
ANALYSIS OF 2D AND 3D GPR RESPONSES IN THE FEDERAL UNIVERSITY OF PARANÁ FORENSIC GEOPHYSICS CONTROLLED SITE - A CASE STUDY
}

\author{
Rafael Espindola Canata1, Francisco José Fonseca Ferreira1', \\ Welitom Rodrigues Borges ${ }^{2}$ and Fábio Augusto da Silva Salvador ${ }^{3}$
}

\begin{abstract}
In 2016, the Laboratory for Research in Applied Geophysics (LPGA), at the Federal University of Paraná, in partnership with the Federal Police of the State of Paraná and the University of Brasília built a Forensic Geophysics Controlled Site (FGCS-UFPR) to calibration of the applied geophysical method and strengthen forensic sciences in the State of Paraná. In the FGCS, several objects that simulate forensic, archaeological and paleontological targets were installed at extremely shallow depths. The materials were covered with clayey soil, typical of the region, and in some pits, fine sandy sediments were deposited. This study aims to verify the 2D and $3 \mathrm{D}$ responses of the ground penetrating radar (GPR) method applied to targets installed in the FGCS, in a postprecipitation period. In the acquisition of GPR data, a $700 \mathrm{MHz}$ shielded antenna was used, with parallel 2D profiles and spaced 0.1 meters. The results indicated that the high clay content present in the soil, below 0.5 meters deep, caused a high attenuation of the electromagnetic signal and defined patterns of reflectors associated with the targets, excavations and the investigated environment. Thus, only targets with high electrical impedance were visualized in 2D and 3D GPR images.
\end{abstract}

Keywords: ground penetrating radar; clay soil; targets; forensic sciences; archaeogeophysics.

RESUMO. Em 2016, o Laboratório de Pesquisas em Geofísica Aplicada (LPGA), da Universidade Federal do Paraná, em parceria com a Polícia Federal do Paraná e a Universidade de Brasília, instalou um Sítio Controlado de Geofísica Forense (SCGF-UFPR) para a calibração do método geofísico aplicado e o fortalecimento das ciências forenses no Estado do Paraná. No SCGF foram instalados, em profundidades extremamente rasas, diversos objetos que simulam alvos forenses, arqueológicos e paleontológicos. Os materiais foram recobertos com solos argilosos, típicos da região, e em algumas cavas foram depositados sedimentos arenosos finos. Este estudo objetiva a verificação das respostas 2D e 3D do método radar de penetração no solo (GPR) aplicada aos alvos instalados no SCG, em um período pós-precipitação pluviométrica. Nas aquisições de dados de GPR foi aplicada a antena blindada de $700 \mathrm{MHz}$, com perfis 2D paralelos e equiespaçados em 0,1 metro. Os resultados indicaram que o alto teor de argila presente no solo, abaixo de 0,5 metro de profundidade, causou uma elevada atenuação do sinal eletromagnético e definiu-se padrões de refletores associados aos alvos, as escavações e ao meio investigado. Assim, apenas os alvos com alta impedância elétrica foram visualizados nas imagens GPR $2 \mathrm{D}$ e $3 \mathrm{D}$.

Palavras-chave: ground penetrating radar; solo argiloso; artefatos; ciência forense; arqueogeofísica. 


\section{INTRODUCTION}

In several countries the geoscientists develop their research on controlled sites that are contextualized as similar areas to those found in distinct cases of research associated to various areas such as environmental, archaeological and forensic (Bowders et al., 1982; Bernhardt et al. 1988; Bevan, 1991; Strongman, 1992; Conyers, 1995; Sauck, 1996; Malagodi et al., 1996; Ivashov et al., 1998; Isaacson et al., 1999; Pipan et al., 1999; Hildebrand et al., 2002; Schultz et al. 2002; Rodrigues \& Porsani, 2006; Pringle et al., 2012; Tinelli et al., 2012; Conyers, 2013; Molina et al., 2015). The test site is built to verify the applicability, improvement and development of geophysical methods and techniques with the objective of minimizing the ambiguities of geophysical responses.

In 2004, in Brazil, built the first controlled site called Shallow Geophysical Test Site I of the IAG/USP (SCGR-I) with the theme focused on urban planning, archaeology and environmental studies. The site is located at USP campus in São Paulo and involving an area of $1500 \mathrm{~m}^{2}$, where artifacts with distinct geometry and composition were installed on site, such as metal and plastic pipes, drums filled with freshwater and saline fluids, shackles of concrete, ceramic vase, pebbles, walls of brick, among others. Over time, several searches were conducted with the objective of imaging, calibrating, characterizing and understanding the geophysical signatures of the artifacts (Porsani et al., 2004; Rodrigues, 2004; Porsani et al., 2006; Borges, 2007).

In Brazil there was a growing interest of researchers in the science called forensic geophysics. As a result, in some regions of the country pioneering controlled site were built such as Forensic Geophysics, Environmental and Rescue (FORAMB in Belém - PA; Nascimento, 2009), the Criminalistics Controlled Site (SITICRIM in Brasília-
DF; Blum \& Russo, 2012) and The Forensic Geophysical Controlled Site (FGCS in Brasília-DF; Cavalcanti et al., 2018).

The FORAMB was built in 2007 in the cemetery of Tapanã, Belém do Pará by Dra. Lúcia Maria da Costa e Silva in partnership with the Necropolis of Department (DANE) and the Legal Medical Institute (LMI). Is this site, research with geophysical methods was developed under simulacrum of weapons and tunnels, besides a human cadaver (Silva et al., 2008; Nascimento, 2009; Catete, 2010; Brasil, 2013).

In 2012, the National Institute of Forensic Sciences of the Brazilian Federal Police (INC) built SITICRIM, whose objective is training of police officers and the improvement of forensic geophysics. In this place are buried artifacts such as projectiles, glasses, computer monitors, weapons, drugs, plastic drums, among others. In the site, researchers from INC and UnB developed and applied different geophysical methods to obtain the characteristic responses of targets buried in latosol (Blum \& Russo, 2012; Alves et al., 2013; Alves et al., 2015; Buso et al., 2016).

The FGCS - UnB, with an area of $600 \mathrm{~m}^{2}$, is located in the 'Água Limpa' Farm, owned by UnB. In this area several pig carcasses were buried to simulate different scenarios of burial at the latosol. Cavalcanti (2017) applied the resistivity and GPR methods in order to detect different burial mechanisms.

Although there are several controlled sites in Brazil, the implementation of new forensic site is of fundamental importance for the improvement of geophysics, in view of different pedological scenarios found in the country. This work aims to present the results of the ground penetrating radar (GPR) method, with $700 \mathrm{MHz}$ shield antennas, for the detection of forensic, archaeological and paleontological targets installed in the FGCS of UFPR. 


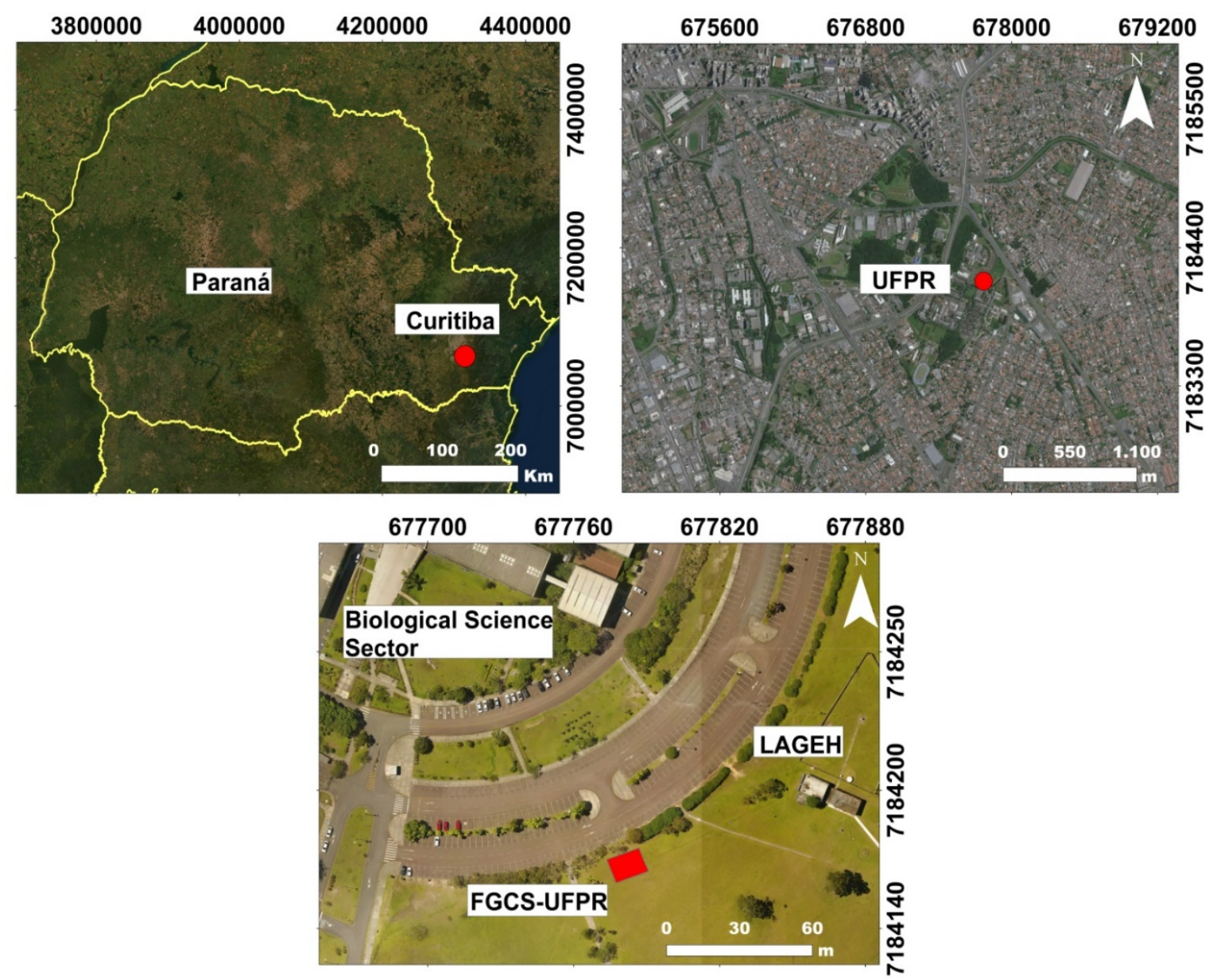

Figure 1 - Location of the Forensic Geophysics Controlled Site in the Polytechnic Campus of the Federal University of Paraná, in Curitiba-PR (Aerial image by drone: Delazari \& Ercolin Filho, 2018).

\section{CONTROLLED SITE OF FORENSIC GEOPHYSICS}

In early December 2016, the first Forensic Geophysics Controlled Site at UFPR (FGCS-UFPR) was implemented, located at the Polytechnic Campus of Curitiba/PR (Fig. 1). After the choice of the place for the construction of the FGCS had been adopted the following stages: demarcation and georeferencing of the polygonal vertices, acquisition of the background with the ground penetrating radar (250 and $700 \mathrm{MHz}$ ), the excavation for installation of the materials and georeferencing (Figs. 2A, 2B, 2C and 2D).
The FGCS-UFPR was installed in the Guabirotuba Formation, first designated by Bigarella et al. (1961), inserted in the Curitiba Basin which is superimposed on the Atuba Complex (migmatite and gneiss). According to these authors the formation is characterized by different lithotypes such as clay, arkose, conglomerate and carbonate deposits (caliche). Felipe (2011) attributed to sediments a deposition age between 23 and 1.8 million years that are associated with the Paleogene to Quaternary periods. During the excavations carried out in the area, a soil profile with two distinct layers was evidenced by means of the tactile-visual method: 


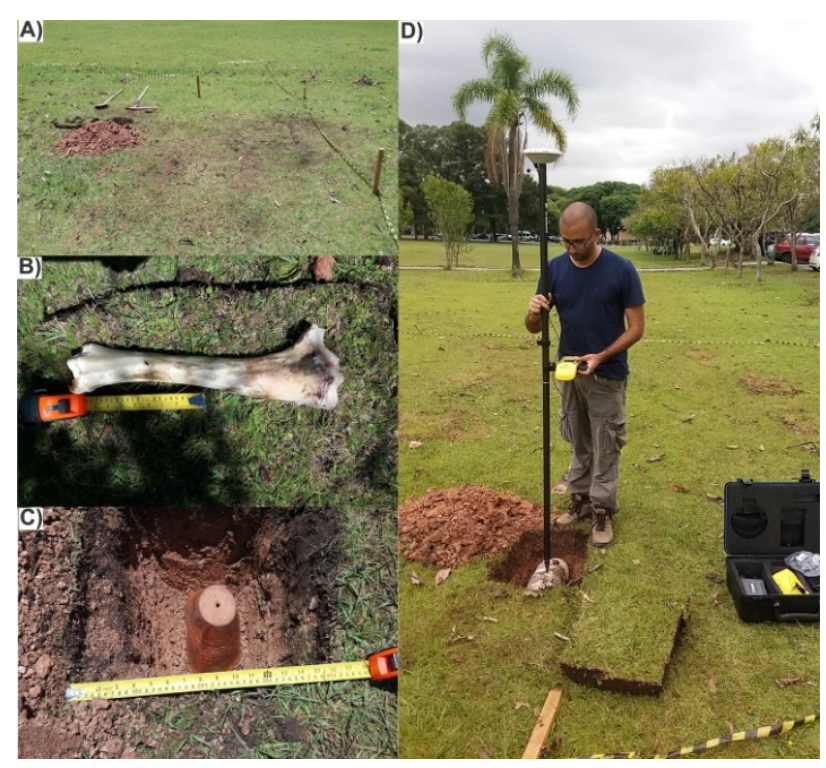

Figure 2 - Photographs show: Preparation for installation of targets in FGCS (A); Illustration of measurements taken from all artifacts $(B)$; Measurements to dimension excavated holes $(\mathrm{C})$; Georeferencing of the base of the hole and the top of all targets installed in FGCS (D).

(i) the surface layer of an organic soil with a dark brown coloration, with thicknesses between 0.15 to $0.20 \mathrm{~m}$; and (ii) overlying layer of clayey soil with the presence of silt and with a reddish-brown coloration, sometimes with alternation of yellowish and grayish tones. In other places, incipient gray clay layers were identified at depths ranging from 0.45 to $0.50 \mathrm{~m}$. The soil characteristic of the site is intrinsically related to the Guabirotuba Formation, i.e., clayey soils.

The implementation of different materials related to areas such as forensics, archaeology and paleontology in the FGCS was intended to simulate possible field situations in which geoscientists and other professionals may come across. Thus, several excavations were carried out to install the objects at shallow depths between $0.13 \mathrm{~m}$ to $0.45 \mathrm{~m}$, totaling 24 holes. Thus, 17 holes were covered with clay soil characteristic of the site, 5 were filled with fine sand and 2 it was decided to insert a small layer of intercalating the two sediments, as seen in the controlled site sketch illustrated (Fig. 3). Table 1 shows the targets installed on the site, the top (TD) and bottom (BD) depths, and the ground on which they are allocated.

\section{METHODOLOGY}

The GPR consists of the continuous irradiation of short pulses of electromagnetic waves to the subsurface by means of a transmitting antenna and, when this wave encounters materials with different electrical impedance, it proves a change in the speed of propagation of the medium and a reflection of part of the irradiated signal to the surface. The reflected signal is captured by the receiving antenna. This data is recorded and stored during the geophysical acquisition through the control unit (Annan \& Cosway, 1992; Jol, 2009; Bigman, 2018).

The acquisition of geophysical data occurred in January 2019, after a rainy period in the region and three years after the installation of targets in FGCS. In the acquisition of GPR data, the Duo Detector system was used with double frequency (250 and $700 \mathrm{MHz}$ ) shielded antennas. Along the controlled site 136 sections of 2D GPR were collected, in constant offset mode (data with continuous recording), with $2 \mathrm{D}$ parallel profiles spaced of $0.10 \mathrm{~m}$ in the $\mathrm{N}-\mathrm{S}$ direction (Figs. 4A, 4B and $4 C$ ). The 2D GPR acquisition parameters used in the field were: 512 samples per trace, time sampling of $0.25 \mathrm{~ns}$, interval between traces (spatial sampling along the section) of $0.027 \mathrm{~m}$ and time window of $120 \mathrm{~ns}$.

The volume of 3D GPR was created from the interpolation of 2D profiles. To georeferenced the 3D GPR data, a steel cable was placed on the ground surface and the antenna was passed 


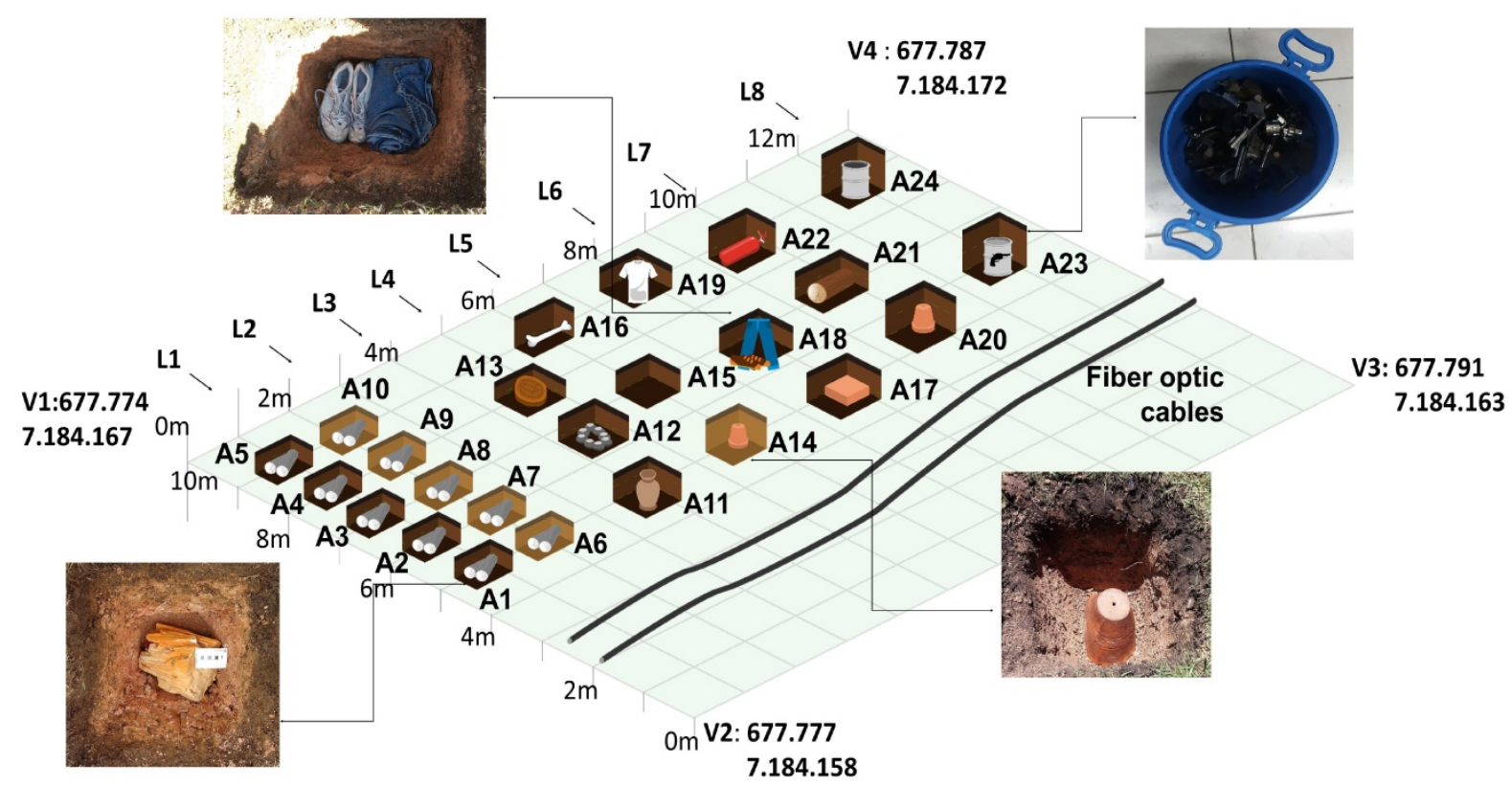

Figure 3 - Sketch of the UFPR Forensic Geophysics Controlled Site, with the spatial location and identification of the materials that were buried in the ground.

Table 1 - The depths related to the top and bottom of the targets and the type of soil in which they were installed.

\begin{tabular}{|c|c|c|c|c|c|c|c|}
\hline Target & $\begin{array}{c}\text { Top } \\
\text { Depth } \\
(\mathbf{m})\end{array}$ & $\begin{array}{c}\text { Bottom } \\
\text { Depth } \\
(\mathbf{m})\end{array}$ & $\begin{array}{c}\text { Soil } \\
\text { Type }\end{array}$ & Target & $\begin{array}{c}\text { Top } \\
\text { Depth } \\
(\mathbf{m})\end{array}$ & $\begin{array}{c}\text { Bottom } \\
\text { Depth } \\
(\mathbf{m})\end{array}$ & $\begin{array}{c}\text { Soil } \\
\text { Type }\end{array}$ \\
\hline A1 - Petrified wood & 0.45 & 0.50 & clay and sand ${ }^{1}$ & A13 - Fossil & 0.17 & 0.20 & clay \\
\hline A2 - Petrified wood & 0.15 & 0.22 & clay & A14 - Ceramic vase & 0.20 & 0.40 & sand \\
\hline A3 - Petrified wood & 0.18 & 0.22 & clay & A15 - Turned over soil & - & 0.40 & clay \\
\hline A4 - Petrified wood & 0.20 & 0.25 & clay & A16 - Bovine femur & 0.42 & 0.50 & clay \\
\hline A5 - Petrified wood & 0.35 & 0.40 & clay & A17 - Solid bricks & 0.30 & 0.35 & clay \\
\hline A6 - Petrified wood & 0.43 & 0.50 & clay and sand 1 & A18 - pair of sneakers and jeans & 0.30 & 0.40 & clay \\
\hline A7 - Petrified wood & 0.15 & 0.20 & sand & A19 - T-shirt & 0.20 & 0.20 & clay \\
\hline A8 - Petrified wood & 0.20 & 0.35 & sand & A20 - Clay vase & 0.20 & 0.40 & clay \\
\hline A9 - Petrified wood & 0.22 & 0.35 & sand & A21 - Wood trunk & 0.13 & 0.30 & clay \\
\hline A10 - Petrified wood & 0.35 & 0.40 & sand & A22 - Extinguisher & 0.32 & 0.40 & clay \\
\hline A11 - Ceramic vase & 0.20 & 0.40 & clay & A23 - Plastic drum with guns & 0.30 & 0.60 & clay \\
\hline A12 - Pebbles & 0.25 & 0.30 & clay & A24 - Plastic drum & 0.30 & 0.60 & clay \\
\hline
\end{tabular}

1 These targets were buried with 0.4 meter of sand and 0.1 meter of clay.

over it during the acquisition, thus the diffraction hyperbole serves as a guide to correct the positioning of the sections.

\section{RESULTS}

The results of the GPR 2D characterized the main targets of the FGCS. The targets were identified through the apexes of the diffraction hyperbolas and presented different sizes, shapes and amplitudes of signals resulting from the different compositions of materials and soil type. In addition, more homogeneous and linear reflectors observed up to a depth of approximately $0.15 \mathrm{~m}$ are associated with a 

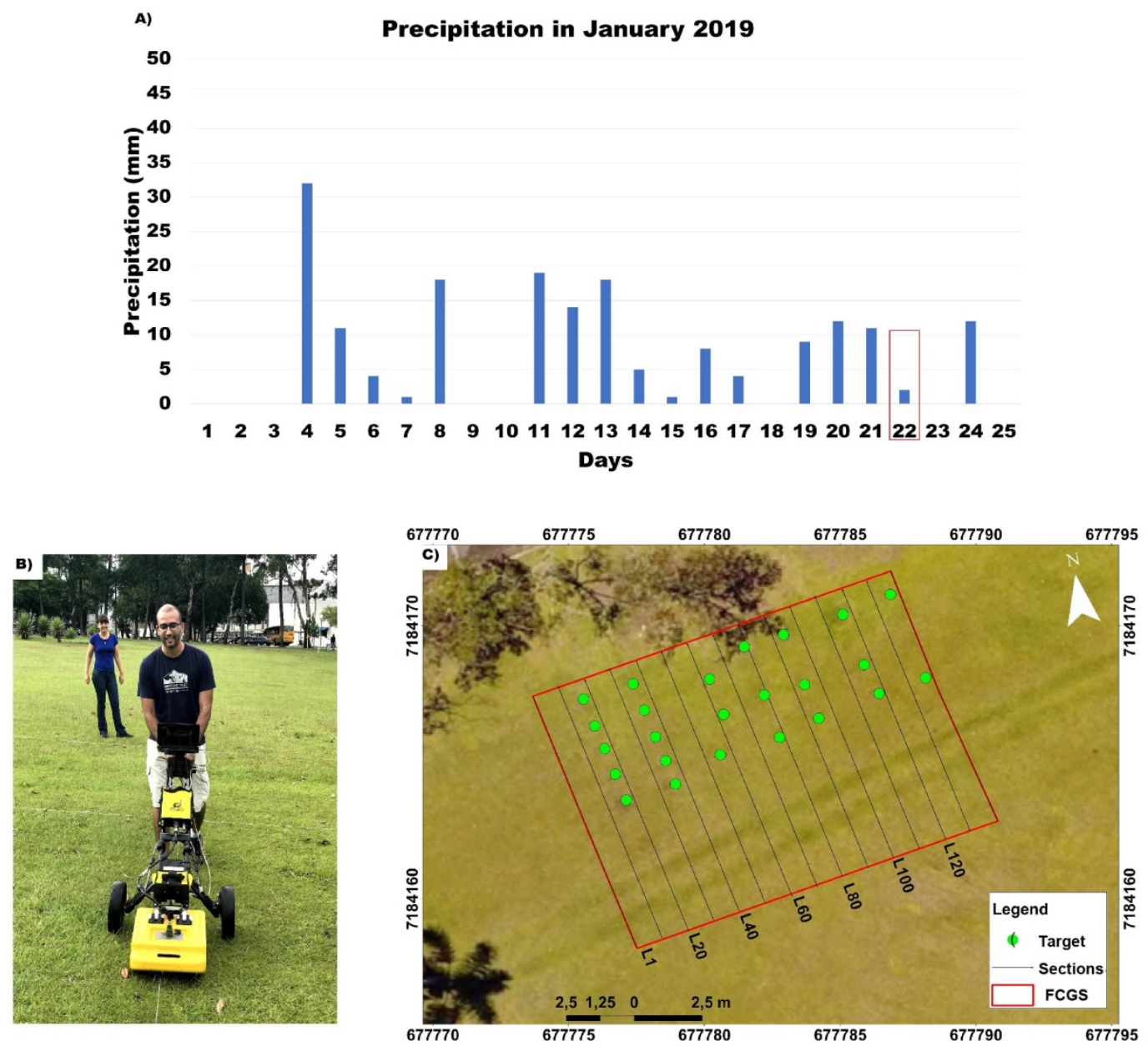

Figure 4-A) Graph showing the rainfall of the month in which the GPR survey was conducted and the red mark indicates the day of acquisition (INMET, 2019); B) Photo illustrating the acquisition with the GPR on a section; C) Georeferenced aerial photography with the arrangement of 2D GPR sections in the FGCS area and the green points indicate the location of the targets (Aerial image by drone by Delazari \& Ercolin Filho, 2018).

more organic soil. In the range of $0.15 \mathrm{~m}$ to 0.65 $\mathrm{m}$ the continuous and random low to medium range reflectors are related to the soil. The interruption of the lateral continuity of these reflectors indicates the presence of excavation structures, i.e., it identifies the location of the excavations carried out for the installation of the targets on the site.

Another parameter obtained was the speed range of the electromagnetic wave in the medium resulting in a variation from $0.053 \mathrm{~m} / \mathrm{ns}$ to $0.066 \mathrm{~m} / \mathrm{ns}$ reflecting soils with high electrical conductivity that results in the attenuation of this wave. This variability in velocity indicates textural heterogeneity caused by anthropic occupation and the moisture present in the soil.

In order to analyze the GPR standards for petrified woods, section L1 was performed at the site that crosses five of these targets. Target A1 was covered with a clay/sand/clay soil and fossils A2 to A5 were installed in a clay soil. As observed the objects are evidenced by the apexes of the diffraction hyperbolas (high amplitude) with time of the hyperbolas corresponding between $5 \mathrm{~ns}$ to $15 \mathrm{~ns}$. In the anomaly $\mathrm{A} 1$ in the time of $8 \mathrm{~ns}$ is observed 

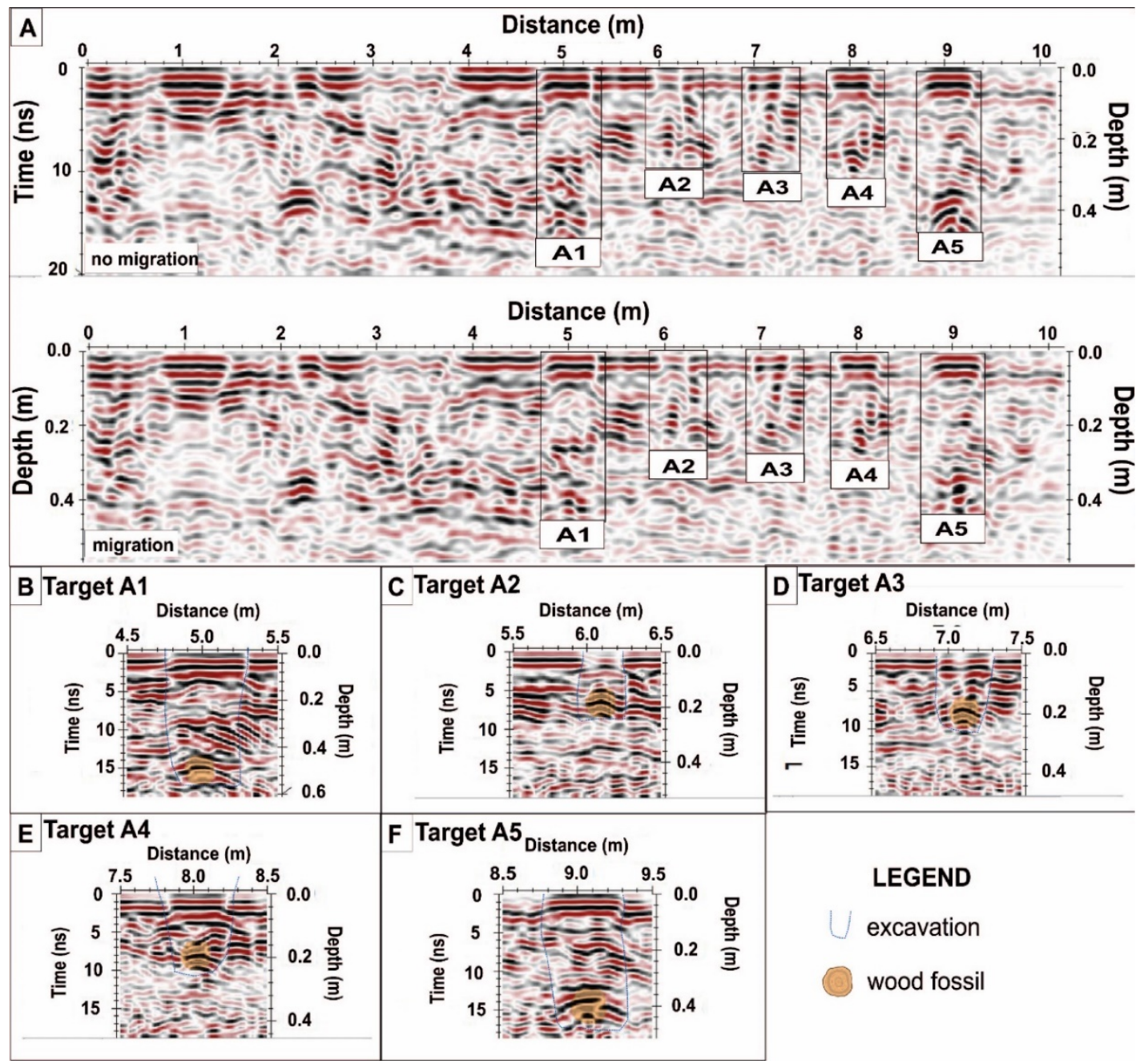

Figure 5- GPR profile with a $700 \mathrm{MHz}$ antenna in Section L1. Profile before (superior panel) and after migration (inferior panel) (A). GPR profile with fossilized trunk in a clayey environment interspersed in the sand (B) and GPR profiles with fossilized trunk at different depths in the clay soil (C, D, E, F).

reflectors with high amplitude that are related to the clay/sand/clay interface, and right below occurs the hyperbole related to the target. As observed in the responses of the other targets there is no presence of these high amplitude reflectors that are associated with small interface of different soils (Fig. 5).

In Section L2 the petrified wood was coated with fine sand (A7-A10, Fig. 3) with the exception of target $A 6$ (coated with sand/clay soil/sand). As previously mentioned, the hyperbolic anomalies of high amplitude mark the fossils. It is noted that the ditch is associated with high reflectivity due to the presence of sand that intensifies the reflection of the electromagnetic signal and a better visualization of hyperbolas occurs (Fig. 6).

When comparing the results of the sections $\mathrm{L} 1$ and $\mathrm{L} 2$ it is observed that the anomalies and the lateral limit of the hole at depths are sharper, due to the dielectric contrast with the medium investigated.

Section L3 transects over the ceramic vase covered with clay soil (A11), a small hyperbole of diffraction was evidenced in the approximate time of 8 ns (top of the object) to 13 ns (base of the object). This medium signal amplitude makes the 


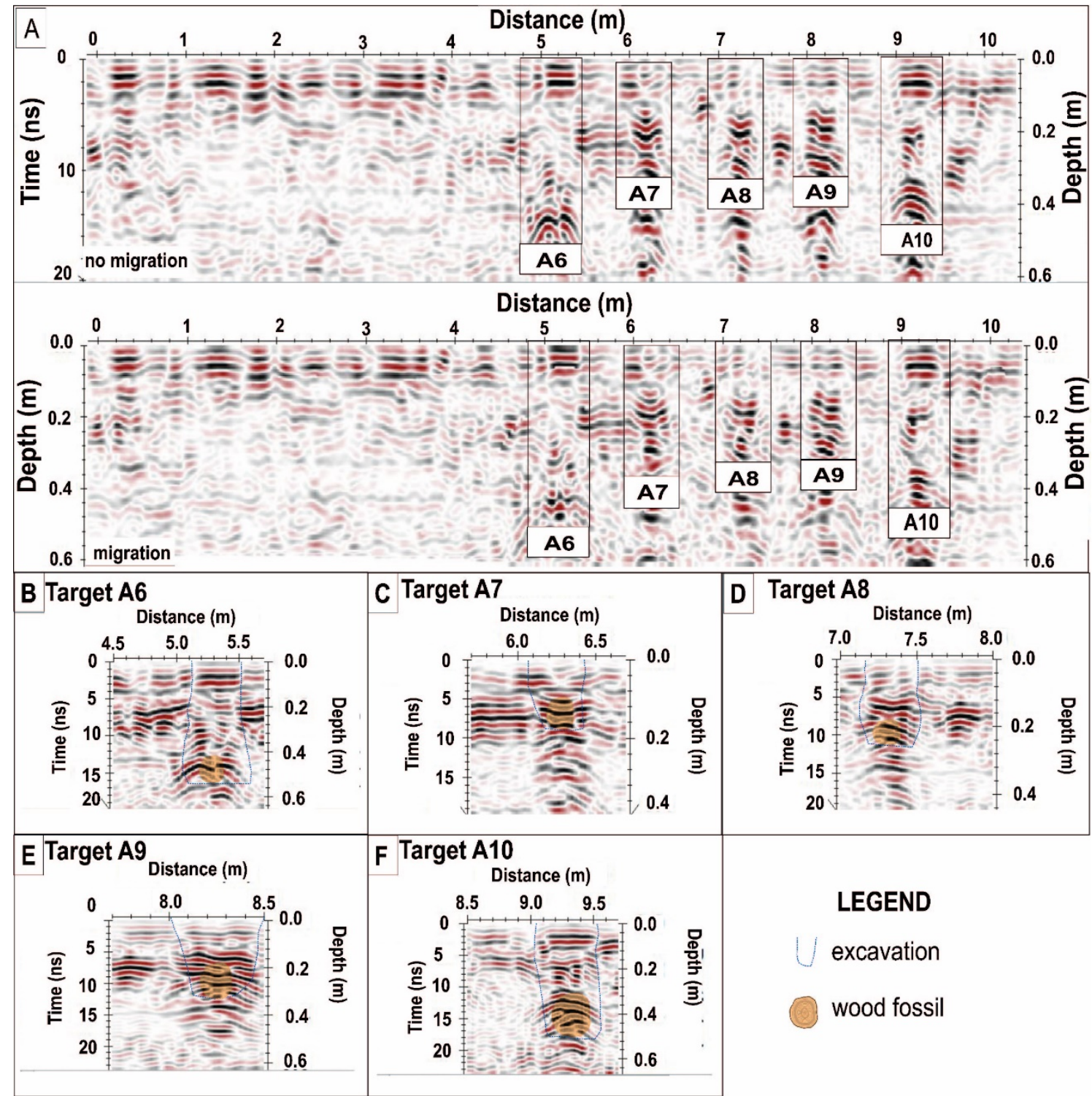

Figure 6 - GPR profile with a $700 \mathrm{MHz}$ antenna in Section L2. Profile before (superior panel) and after migration (inferior panel) (A). GPR profile with fossilized trunk in a sand environment interspersed in the clay (B) and GPR profiles with fossilized trunk at different depths in the sand soil (C, D, E, F).

visualization of this artifact difficult, and this occurs due to the low impedance contrast that occurs between the target and the medium investigated (Fig. 7).

Section L4 (Fig. 8) contains pebbles of various sizes and a small fossil and are inserted in the clay soil (A12 and A13). The pebbles are represented by the intersection of two hyperbolic reflections with high amplitude, and are in the approximate depth of $0.25 \mathrm{~m}$. The fossil is represented by a low amplitude hyperbole due to the low contrast of electrical impedance with the soil.

In Section L5 (Fig. 9) was installed a ceramic vase, a turned over soil and a bovine bone (A14, $\mathrm{A} 15$, and A16). Among the targets, only the ceramic vase was detected due to the sandy environment in which it is inserted. In this target, a first reflection at $0.20 \mathrm{~m}$ was related to the top of the object and a second reflection at a depth of $0.40 \mathrm{~m}$ was associated with its base. Ceramic vases or fragments (archaeological artifacts) are usually identified by hyperbolic reflectors in a 


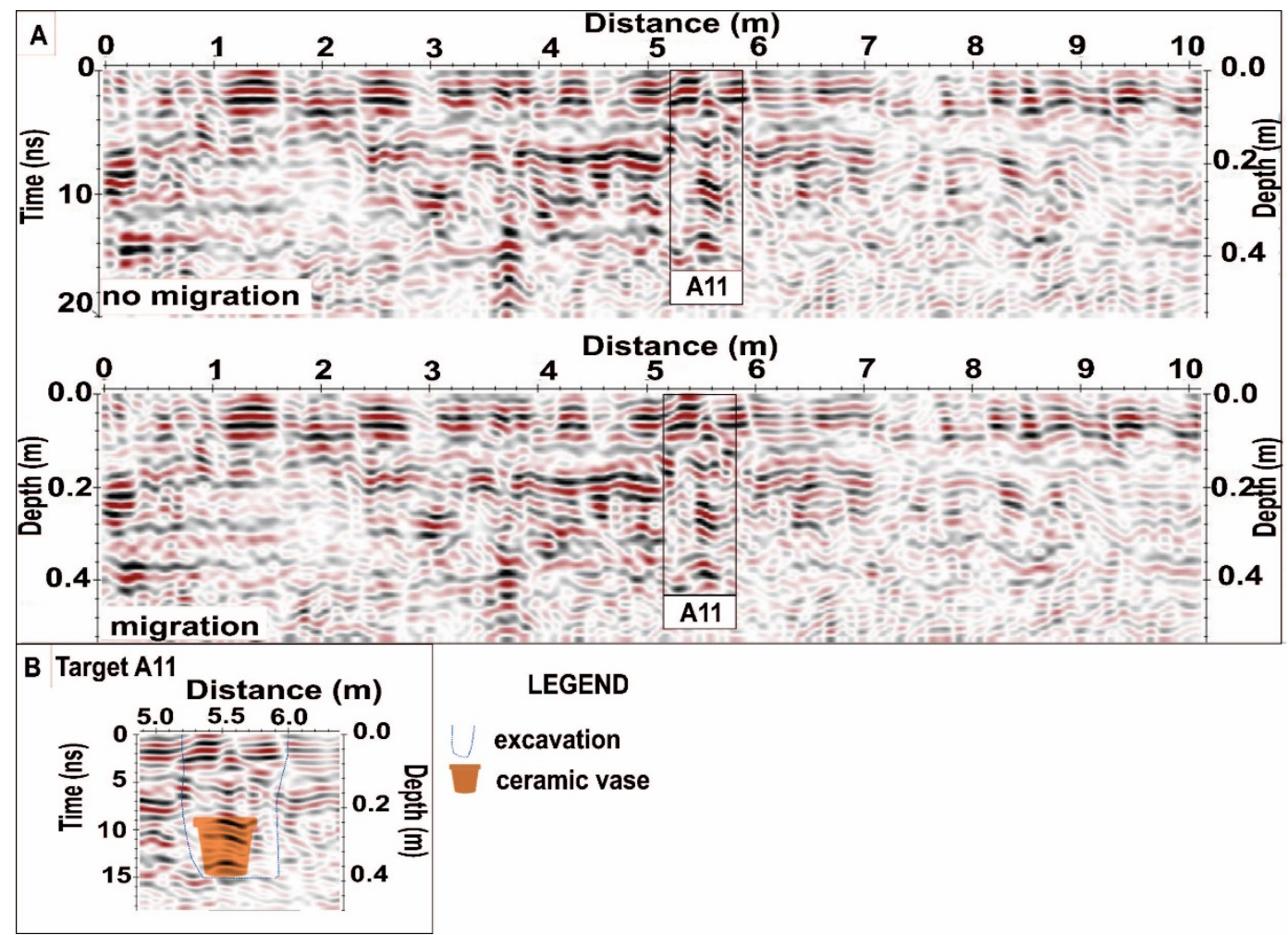

Figure 7 - GPR profile with a $700 \mathrm{MHz}$ antenna in Section L3. Profile before (superior panel) and after migration (inferior panel) (A). GPR profile with ceramic vase (B).

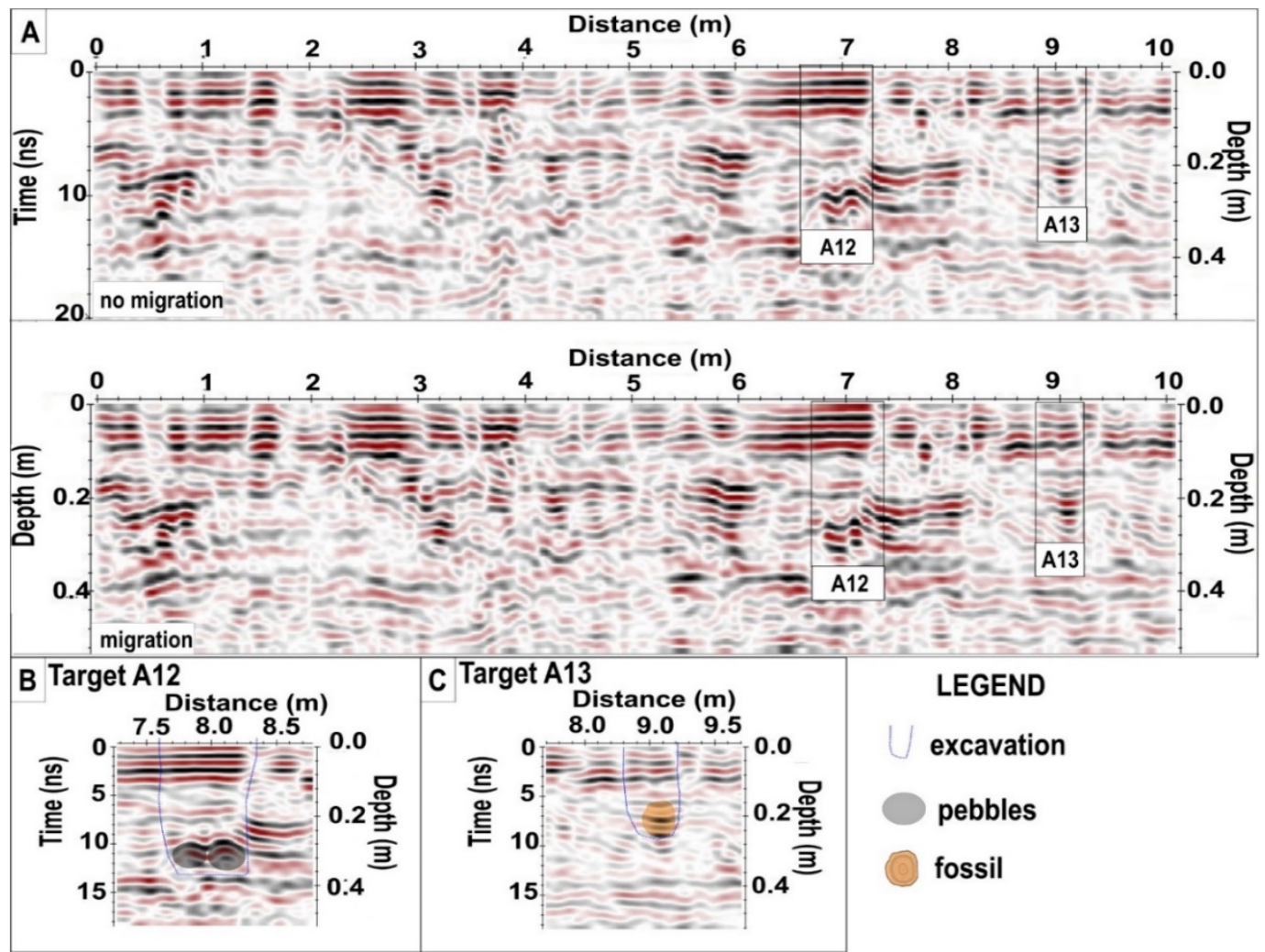

Figure 8 - GPR profile with a $700 \mathrm{MHz}$ antenna in Section L4. Profile before (superior panel) and after migration (inferior panel) (A). GPR profile with pebbles and fossil at different depths (B) and (C). 


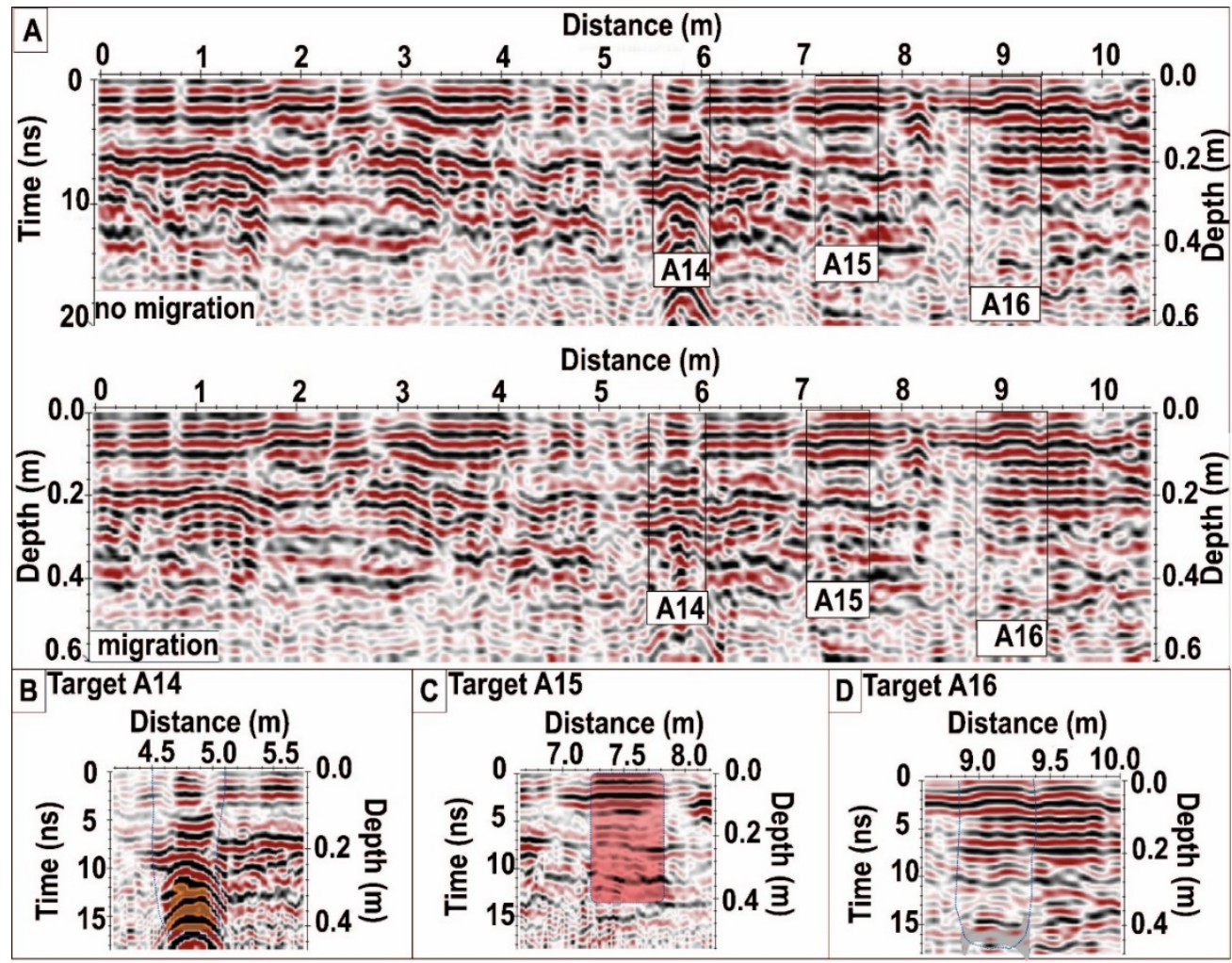

\section{LEGEND}

excavation

ceramic vase

stirred soil

$\checkmark$ bovine femur

Figure 9 - GPR profile with a $700 \mathrm{MHz}$ antenna in Section L5. Profile before (superior panel) and after migration (inferior panel) (A). GPR profile with ceramic vase in a sand soil (B) and GPR profile with turned over soil and bovine femur at different depths in the clay soil (C, D).

geophysical-archaeological investigation, however in some cases they can be confused with anomalies related to roots (Aragão et al., 2010; Porsani et al., 2010).

Note that in Figure $9 \mathrm{~B}$ there are reverberations inside the ceramic vase, this is due to the air present, that is, a sudden change of speed between the air/clay soil interfaces. The other two targets were probably not detected due to the homogeneity and humidity of the soil and the low contrast of reflection between the bovine bone and the surrounding environment. Borges (2007) reports that this lack of reflection in an overturned soil is related due to homogeneity, consistent with the result of Figure 9C.

In Section L6 (Fig. 10) the installed targets correspond to two solid bricks; a pair of sneakers, a pair of jeans; and a T-shirt, and all inserted in clay soil (A17, A18, and A19). The solid brick is identified through a hyperbolic reflector with low intensity, due to the low contrast of electrical impedance between the materials (clay soil/tiles). The synthetic materials absorb the water from the soil, impairing the imaging of these targets, i.e., the electromagnetic wave is probably being dissipated. Solla et al. (2012) verify that the 


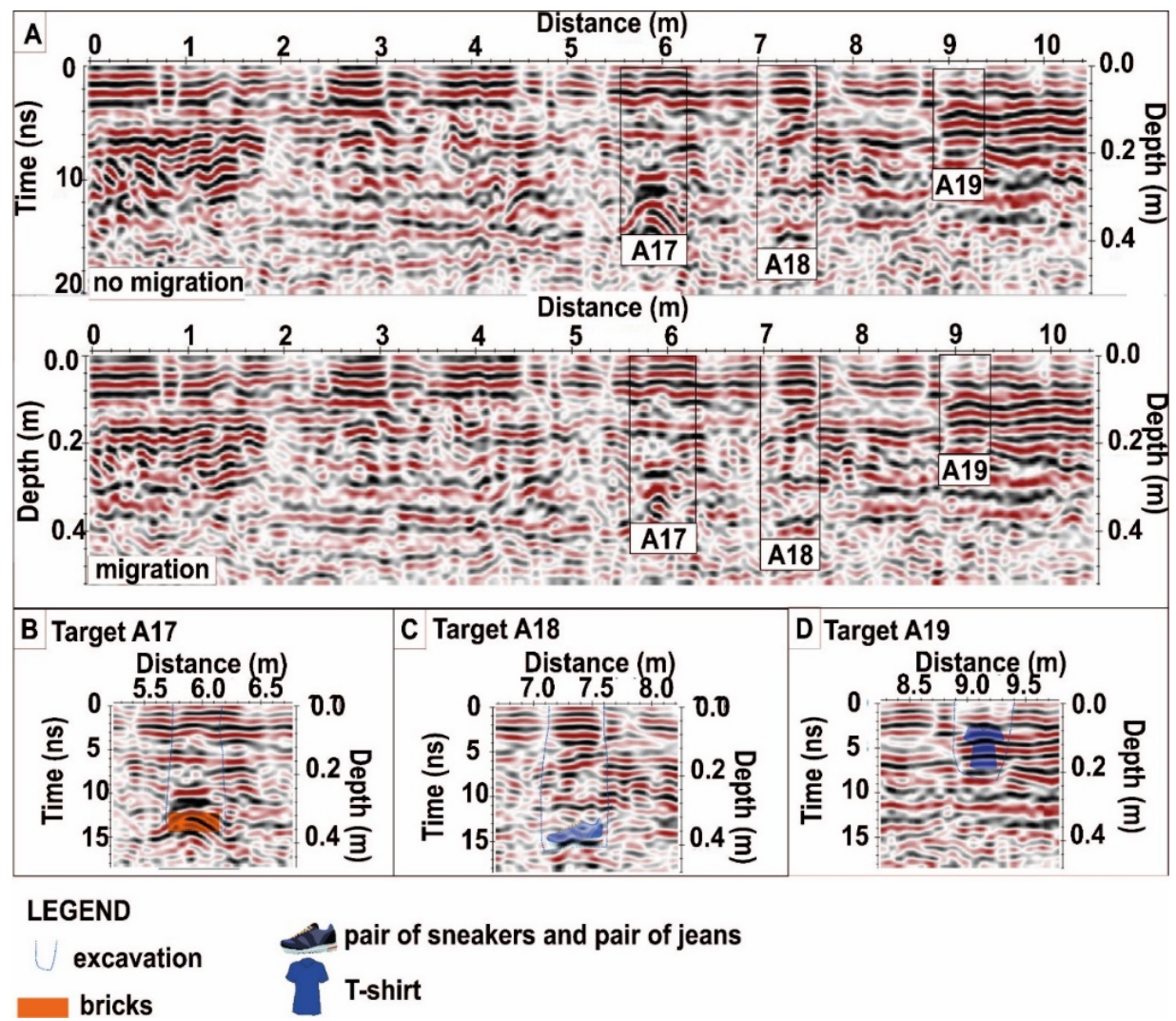

Figure 10 - GPR profile with a $700 \mathrm{MHz}$ antenna in Section L6. Profile before (superior panel) and after migration (inferior panel) (A). GPR profile with solid bricks, pair of sneakers and pair of jeans, and T-shirt at different depths in the clay soil $(B, C, D)$.

detection of clothing and personal items is possible in sand-clay soil and these materials are concentrated in the same place, causing an increase in the volume for investigation.

Section L7 (Fig. 11) includes a clay vase, a wood trunk and an extinguisher (A20, A21 and A22), also inserted in clay soil. All targets were detected by high amplitude hyperbolic reflectors. It should be noted that in the result for the wood trunk two reflections in the intervals of $0.15 \mathrm{~m}$ and $0.30 \mathrm{~m}$ depths related to the top and bottom were recognized. Targets $\mathrm{A} 14$ and $\mathrm{A} 20$ are associated to ceramic and clay vase, respectively, it is observed some differences in the reflectors responses regarding amplitude, size, and hyperbolic opening that are larger in a sandy medium (A14) due to the radar beam opening and the dielectric contrast difference between the medium and the target.
In Section L8 (Fig. 12) two 30-liter plastic drums are installed: one semi-filled with destroyed weapons (A23) and the other empty (A24), and are inserted in clay soil. At the target A23 the top is related to the reflection vertex with a high amplitude at the depth of $0.30 \mathrm{~m}$ and attenuation of the intensity of the reflectors probably related to wave dissipation under the damaged weapons. On the target A24, because it is empty, only the reflection related to the top of the bomb is identified. Rodrigues \& Porsani (2006) studied the GPR responses in plastic drums at the IAG-USP Shallow Geophysical Test Site I and identified that when the plastic drums are empty only the top can be identified, this occurs due to the overlap of reflectors caused by the speed of electromagnetic wave propagation being greater inside the drum than in clay soil. 


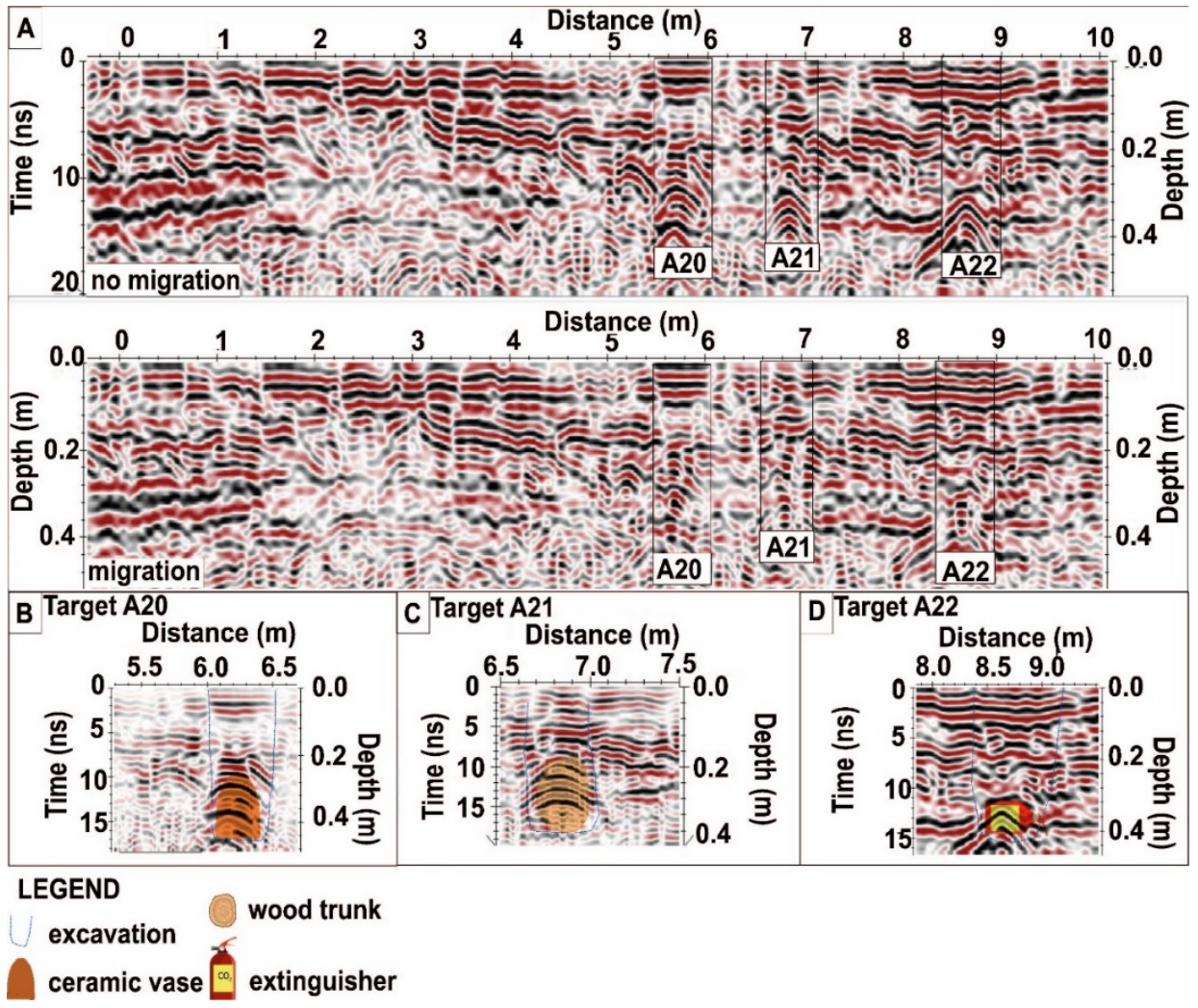

Figure 11 - GPR profile with a $700 \mathrm{MHz}$ antenna in Section L7. Profile before (superior panel) and after migration (inferior panel) (A). GPR profile with ceramic vase, wood trunk, and extinguisher at different depths in the clay soil (B, C, D).

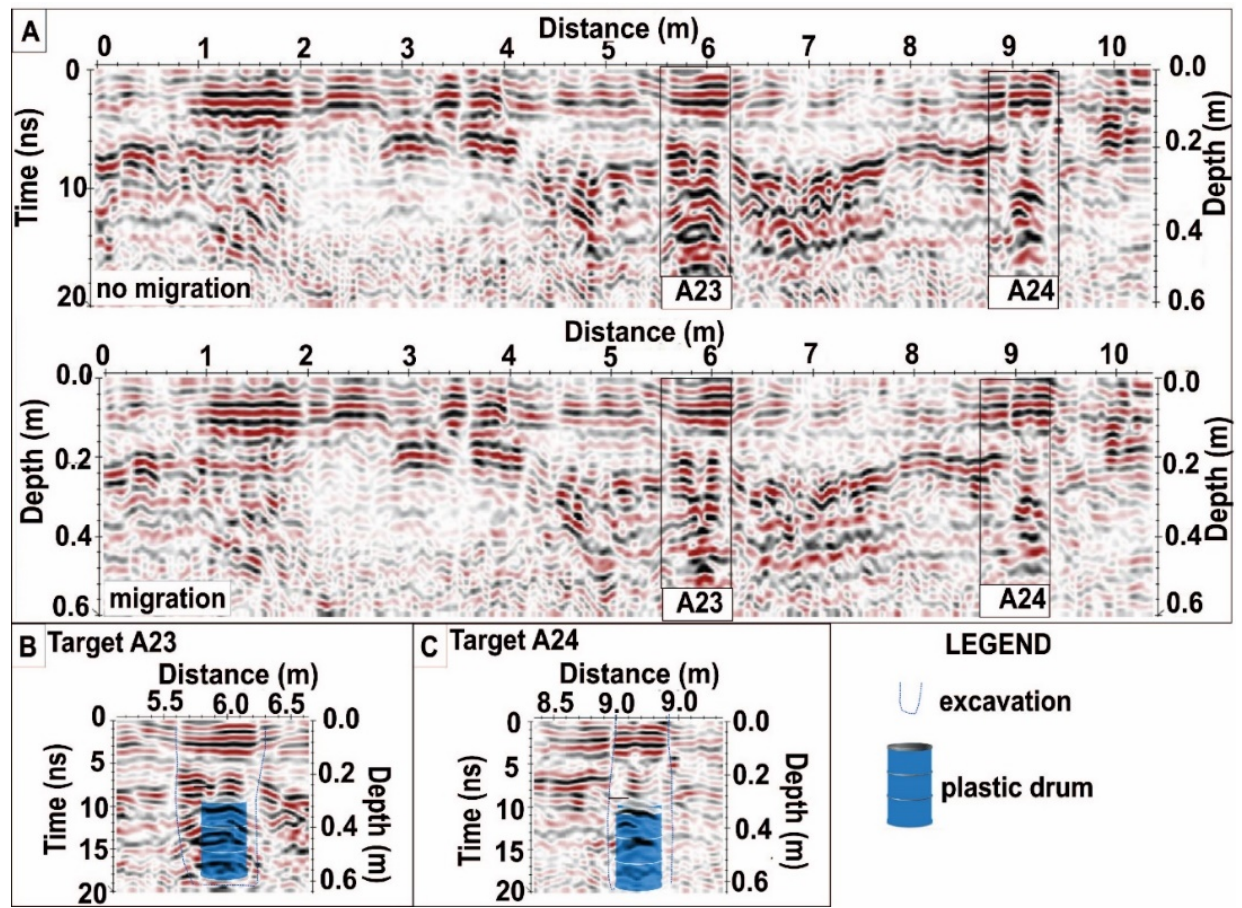

Figure 12- GPR profile with a $700 \mathrm{MHz}$ antenna in Section L8. Profile before (superior panel) and after migration (A) (inferior panel). GPR profile with plastic drum with destroyed weapons in the clay soil (B) and GPR profile with plastic drum empty in the clay soil (C). 

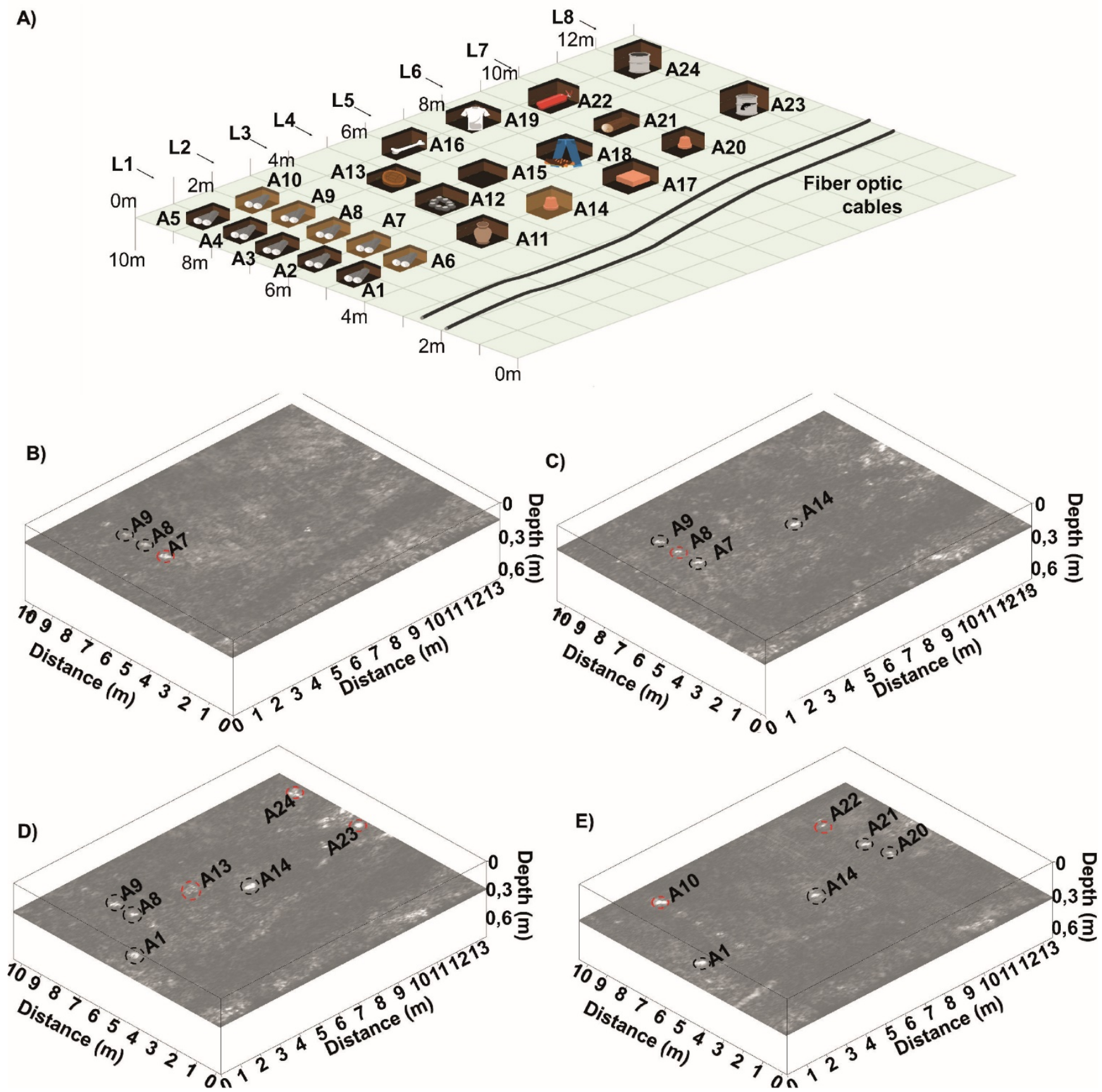

Figure 13 - (A) Sketch illustration of the FGCS-UFPR. Cuts at depths in a 3D block with $700 \mathrm{MHz}$ antenna radargrams with the image of the following targets: $(B)$ Fossils at a depth of $0.15 \mathrm{~m}$; (C) Ceramic vase covered with sand (A14), petrified wood $(A 7, A 8$ and $A 9)$ at a depth of $0.25 \mathrm{~m}$; (D) plastic drums (A23 and $A 24)$, pebble base (A13), ceramic vase (A14) and petrified wood $(A 1, A 8$ and $A 9)$ in the depth of $0.30 \mathrm{~m}$; $(E)$ petrified wood ( $A 1$ and $A 10)$, clay and ceramic vases $A 20$ and $A 14$, wood trunk A21 and A22 extinguisher observed in the depth of $0.32 \mathrm{~m}$. Red and black circles indicate real depth and detection of the target respectively.

The 3D volume was built to estimate the depth of the investigated targets, their spatial positioning, and geometric shape. The image targets and their locations were marked by a point reflectance with high signal amplitude and were indicated by dotted circles in red (real depth) and black (detection of the targets), respectively, in Figure $13(B, C, D$ and $E)$. The results of the $3 D$ 
block through the depth slice are presented in four different depths: (i) in $0.15 \mathrm{~m}$, three anomalies (A7, A8, and A9) are associated with petrified wood fossils covered with fine sand, Figure 13B; (ii) in $0.25 \mathrm{~m}$, the marked anomalies correspond to the ceramic vase covered with fine sand (A14) and the petrified wood (A7, A8, and $\mathrm{A} 9$ ), Figure 13C; (iii) at a depth of $0.30 \mathrm{~m}$, several anomalies were observed associated with the targets corresponding to plastic drums (A23 and $A 24)$, petrified wood ( $A 1, A 8$, and $A 9)$, pebbles (A12) and ceramic vase (A14), Figure 13D; and in $0.32 \mathrm{~m}$ six anomalies (A1, A10, A14, A20, A21, and $A 22$ ) representing the petrified wood, the fire extinguisher and the bases of the wood trunk and clay vase, Figure 12E. The non-detection of the other targets is intrinsically related to the low electrical impedance of the medium and mainly to the presence of humidity in subsurface.

\section{CONCLUSION}

The implementation of the first controlled site in the State of Paraná proved to be an important tool for the dissemination of forensic geosciences at the Federal University of Paraná, as well as in the training of federal and civilian experts.

The application of GPR (700 MHz) after a long period of rainfall, which causes an increase in soil moisture and conductivity, proved to be satisfactory, making it possible to calibrate reflection patterns of the vast majority of targets installed in the FGCS. As well as the interpretation of reflectors associated with disturbances in the ground related to the excavations carried out in 2016 , this type of feature is often the object of study in forensic geophysics. The interpreted results made it possible to identify different patterns of anomalies related to the targets, however some forensic targets (jeans, sneakers, T-shirts) could not be imaged due to their textile composition which probably became more stubborn. Pseudo 3D models showed satisfactorily the depths, geometric and spatial shapes of the targets present in the FGCS. Mainly, the targets that were covered with fine sand provided a better view.

The GPR responses obtained in the $2 \mathrm{D}$ sections, in some cases, were more efficient than those observed in the 3D block. However, joint acquisition and interpretation are of fundamental importance to characterize and differentiate the types of targets present in the subsoil.

\section{ACKNOWLEDGMENTS}

The authors would like to thank the forensic criminologist unit of the Brazilian Federal Police in State of Paraná and Santa Catarina State University for their collaboration in research. F.J.F. Ferreira was supported in this research by a fellowship from the National Council for Scientific and Technological Development, CNPq (ID: 303826/2018-5) and R.E. Canata was supported in this research by a fellowship from the Coordination for the Improvement of Higher Education Personnel, CAPES (ID: 03741868981), Ministry of Education, Brazil.

\section{REFERENCES}

ALVES LK, BORGES WR \& BLUM MLB. 2013. Mapeamento de alvos forenses com GPR 3D. In: International Congress of the Brazilian Geophysical Society, 13., 2013, Rio de Janeiro. Proceedings... Rio de Janeiro, Brazil: SBGf, 2013. CD-ROM.

ALVES LK, BORGES WR \& BLUM MLB. 2015. Análise forense de dados de GPR 3D usados para 
identificar ossada de animais e recipientes de vidro. In: International Congress of the Brazilian Geophysical Society, 14., 2015, Rio de Janeiro. Proceedings...Rio de Janeiro, Brazil: SBGf, 2015. CD-ROM.

ANNAN AP \& COSWAY SW. 1992. Ground penetrating radar survey design. In: Proceedings of the Symposium on the Application of Geophysics to Engineering and Environmental Problems. SAGEEP'92. Oakbrook, Illinois, pp. 329-351, April 26-29.

ARAGÃO RC, LUIZ JG \& LOPES PRC. 2010. Metodologia geofísica aplicada ao estudo arqueológico dos sítios Bittencourt e Jambuaçu, Estado do Pará. Revista Brasileira de Geofísica, 28(2): 249-263.

BERNHARDT B, LANDINI W, VAROLA A. 1988. Georadar and its use in Paleontology. Boll. Soc. Paleontol. Ital., 27(2): 245-251.

BEVAN BW. 1991. The search for graves. Geophysics, 56(6): 1310-1319.

BIGARELLA JJ, SALAMUNI $R$ \& AB'SABER AN.1961. Origem e ambiente de deposição da Bacia de Curitiba. Boletim Paranaense de Geografia, 4(5): p.71-81.

BIGMAN DP. 2018. GPR Basics: A Handbook for Ground Penetrating Radar Users. Bigman Geophysical. 135 pp.

BORGES WR. 2007. Caracterização geofísica de alvos rasos com aplicações no planejamento urbano e meio ambiente: Estudo sobre o sítio controlado do IAG/USP. Doctorate Thesis on Geophysics - Programa de Pós-graduação em Geofísica, Universidade de São Paulo, SP, Brazil, 2007. 260 pp.

BOWDERS Jr JJ, KOERNER RM \& LORD Jr AE. 1982. Buried container detection using ground-probing radar. Journal of Hazardous Materials, 7: 1-17.

BLUM MLB \& RUSSO D. 2012. SITICRIM Brazilian Test Site for Forensic Geophysical Research. In: European Academy of Forensic
Science Conference. 2012, The Hague, Netherlands: EAFS, poster.

BRASIL DL. 2013. Investigação Geofísica forense e antropológica com método GPR no cemitério do Tapanã e no cemitério perdido de Mosqueiro (Belém, Pará). Master Dissertation on Geophysics - Programa de Pós-graduação em Geofísica, Universidade do Pará, PA, Brazil, 2013. 94 pp.

BUSO ASO, BLUM MLB \& BORGES WR. 2016. Imageamento GPR 3D de alvos forenses na área sítio controlado de criminalística (SITICRIM). In: VII Simpósio Brasileiro de Geofísica. 2016, Ouro Preto. Anais... Ouro Preto, CD-ROM.

CATETE CP. 2010. Investigações ambiental e forense com os métodos geofísicos radar de penetração do solo, polarização induzida e eletrorresistividade no cemitério do Tapanã, Belém/Pará. Master Dissertation on Geophysics - Programa de Pós-graduação em Geofísica, Universidade Federal do Pará, PA, Brazil, 2010. 90 pp.

CAVALCANTI M. 2017. Estudos das respostas geofísicas em diferentes cenários de sepultamentos. PhD Thesis on Geophysiscs Programa de Pós-graduação em Geociências Aplicadas e Geodinâmica, Universidade de Brasília, DF, Brazil. 2017. 197 pp.

CAVALCANTI M, ROCHA MP, BLUM MLB \& BORGES WR. 2018. The Forensic geophysical controlled research site of the University of Brasilia, Brazil: Results from methods GPR and electrical resistivity tomography. Forensic Science International, 293: 101.e1-101.e21.

CONYERS LB. 1995. The use of groundpenetrating radar to map the buried structures and landscape of the ceren site, El Salvador, Geoarchaeology, 10(4): 275-299.

CONYERS LB. 2013. Ground-penetrating radar studies at the HAMMER Test Bed Facility, Richland, Washington. Journal of Northwest Anthropology, 47(2): 153-166. 
DELAZARI LS \& ERCOLIN FILHO L. 2018. Projeto UFPR CampusMap. Curitiba: UFPR, CEPAG Centro de Pesquisas Aplicadas em Geoinformação. Project in Progress. Available on: $<w w w . c a m p u s m a p . u f p r . b r>$. Access on: August 15, 2019.

FELIPE RS. 2011. Características GeológicoGeotécnicas na Formação Guabirotuba Erosãomovimentos Gravitacionais de Massa. Curitiba: MINEROPAR - Serviço Geológico do Paraná, 2011. PR, Brazil.

HILDEBRAND JA, WIGGINS SM, HENKART PC \& CONYERS LB. 2002. Comparison of seismic reflection and ground-penetrating radar imaging at controlled archaeological test site. Archaeological Prospection, 9: 9-21.

INMET - INSTITUTO NACIONAL DE METEROLOGIA. 2019. Brazil. Available on: <https://portal.inmet.gov.br/> Access on: March 5, 2019.

ISAACSON J, HOLLINGER ER, GRUNDUM D \& BAIRD JA. 1999. A controlled archaeological test site facility in Illinois: Training and Research in Archaeogeophysics. Journals of Field Archaeological, 26(2): 227-236.

IVASHOV SI, VYACHESLAV NS, SHEYKO AP \& VASILIEV IA. 1998. GPR for detection and measurement of filled up excavations for forensic applications. In: Seven International Conference Ground-Penetrating Radar. The University of Kansas, Lawrence, Kansas, USA, p. 86-89.

JOL HM. 2009. Ground Penetrating Radar Theory and Applications. Elsevier, Amsterdam, The Netherlands, $544 \mathrm{pp}$.

MALAGODI S, ORLANDO L, PIRO S, ROSSO F. 1996. Location of archaeological structures using GPR method: three-dimensional data acquisition and radar signal processing. Archaeological Prospection, 3: 13-23.

MOLINA CM, PRINGLE JK, SAUMENTT M \& HERNÁNDEZ O. 2015. Preliminary results of sequential monitoring of simulated clandestine graves in Colombia, South America, using ground penetrating radar and botany. Forensic Science International, 248: 61-70.

NASCIMENTO WG. 2009. Investigação geofísica ambiental e forense nos cemitérios do Bengui e do Tapanã (Belém, Pa). Master Dissertation on Geophysics - Programa de Pós-graduação em Geofísica, Universidade Federal do Pará, PA Brazil, 2009, 153 pp.

PIPAN M, BARADELLO L, FORTE E, PRIZZON A \& FINETTI I. 1999. 2-D and 3-D processing and interpretation of multi-fold ground penetrating radar data: a case history from an archaeological site. Journal of Applied Geophysics, 41: 271-292.

PORSANI JL, BORGES WR, ELIS VR, DIOGO LA, HIODO FY, MARRANO A \& BIRELLI CA. 2004. Investigações Geofísicas de Superfície e de Poço no Sítio Controlado de Geofísica Rasa do IAG-USP. Revista Brasileira de Geofísica, 22(3): 245-258.

PORSANI JL, BORGES WR, RODRIGUES SI \& HIOGO FY. 2006. O Sítio Controlado de Geofísica Rasa do IAG USP: Instalação e resultados GPR 2D3D. Revista Brasileira de Geofísica, 24(1): 49-61.

PORSANI JL, JANGELME GM \& KIPNIS R. 2010. GPR survey at Lapa do Santo archaeological site, Lagoa Santa karstic region, Minas Gerais state, Brazil. Journal of Archaeological Science, 37(12): 1141-1148.

PRINGLE JK, JERVIS JR, HANSEN JD, JONES GM, CASSIDY NJ \& CASSELLA JP. 2012. Geophysical monitoring of simulated clandestine graves using electrical and ground penetrating radar methods: 0-3 years after burial. Journal of Forensic Science, 57: 1467-1486.

RODRIGUES SI. 2004. Caracterização GPR de tambores metálicos e plásticos: Estudos sobre o sitio controlado do IAG/USP. Master Dissertation on Geophysics - Programa de Pós-graduação em Geofísica, Universidade de São Paulo, SP, Brazil, 2004, 102 pp. 
RODRIGUES SI \& PORSANI JL. 2006. Utilização do GPR para caracterizar tambores de plásticos enterrados no Sítio Controlado de Geofísica Rasa do IAG/USP. Brazilian Journal of Geophysics, 24(2): 157-168.

SAUCK W. 1996. Controlled Site for Shallow Geophysics. Institute for Water Sciences, Department of Geosciences, Western Michigan University. Internal Report. USA.

SCHULTZ JJ. 2012. The Application of Ground Penetrating Radar for Forensic Grave Detection. In: DIRKMAAT DC. A Companion to Forensic Anthropology. Blackwell Publishing Ltd. chapter 4 p. 85-100. doi: 10.1002/9781118255377.ch4.

SILVA LMC, NASCIMENTO WG, LUIZ JG, COSTA AAS \& CATETE CP. 2008. FORAMB: campo de testes controlados para Geofísica
Forense, Ambiental e de Resgate, Belém/PA. In: III Simpósio Brasileiro de Geofísica. Belém, PA, Brazil, 2008.

SOLLA M, RIVEIRO B, ALVARÉS XM \& ARIAS P. 2012. Experimental forensic scenes for the characterization of ground-penetrating radar. Forensic Science International, 220: 50-58.

STRONGMAN KB. 1992. Forensic applications of ground penetrating radar. In: PILON $\mathrm{J}$ (Ed.). Ground Penetrating Radar. Geological Survey of Canada, Paper 90-4, p. 203-2011.

TINELLI C, RIBOLINI A, BIANUCCI G, BINI M \& LANDINI W. 2012. Ground penetrating radar and palaeontology: The detection of sirenian fossil bones under a sunflower field in Tuscany (Italy). Comptes Rendus Palevol, 11: 445-454. 